\title{
Highly disjunct and highly infected millipedes - a new cave-dwelling species of Chiraziulus (Diplopoda: Spirostreptida: Cambalidae) from Iran and notes on Laboulbeniales ectoparasites
}

\author{
Ana Sofia P.S. REBOLEIRA ${ }^{1}$, Mohamad Javad MALEK HOSSEINI ${ }^{2}$, Saber SADEGHI ${ }^{3}$ \& \\ Henrik ENGHOFF ${ }^{4}$ \\ ${ }^{1,4}$ Zoological Museum, Natural History Museum of Denmark, University of Copenhagen, \\ Universitetsparken 15, DK-2100 Copenhagen Ø, Denmark. \\ ${ }^{2}$ Department of Biology, Payame Noor University (PNU), Yasouj, Iran. \\ ${ }^{2,3}$ Department of Biology, College of Sciences, Shiraz University, Iran. \\ ${ }^{1}$ Email: sreboleira@snm.ku.dk (corresponding author) \\ ${ }^{1}$ urn:1sid:zoobank.org:author:338DE845-4839-4EF5-B684-587C021F076C \\ ${ }^{2}$ urn:1sid:zoobank.org:author:54DE1791-C6F7-4C81-99DD-736BFC2F7A9F \\ ${ }^{3}$ urn:1sid:zoobank.org:author:B21098A7-8D55-43A9-96D9-D3C088219D63 \\ ${ }^{4}$ urn:lsid:zoobank.org:author:FB09A817-000D-43C3-BCC4-2BC1E5373635
}

\begin{abstract}
Chiraziulus is a highly disjunct, hitherto monotypic genus of cambalid millipedes, geographically isolated in Iran by more than $7000 \mathrm{~km}$ from its presumed closest relatives in East Asia and North America. Recent fieldwork in caves of Iran has provided several specimens of this genus, allowing the description of Chiraziulus troglopersicus sp. nov. The intraspecific variability of the type species, C. kaiseri Mauriès, 1983, is illustrated with scanning electron micrographs. Chiraziulus is characterized by exceedingly long microtrichose gonopod flagella which from their insertion points on the posterior face of the anterior gonopod coxites first point distad instead of basad or basad-posteriad as in most other flagelliferous Cambalidea (and Julida), then traverse a groove on the mesal surface of the anterior gonopod coxites, making a full $\left(360^{\circ}\right)$ loop. The same feature is also illustrated for the first time in the genus Cambala. The patterns and prevalence of the infection with a species of ectoparasitic fungus of the genus Rickia (order Laboulbeniales) in the type material of C. kaiseri is described. An updated review of the cave-adapted fauna of Iran is given.
\end{abstract}

Key words. Cave-adapted, troglobiont, karst, Zagros, Iran, ectoparasitic fungus.

Reboleira A.S.P.S., Malek Hosseini M.J., Sadeghi S. \& Enghoff H. 2015. Highly disjunct and highly infected millipedes - a new cave-dwelling species of Chiraziulus (Diplopoda: Spirostreptida: Cambalidae) from Iran and notes on Laboulbeniales ectoparasites. European Journal of Taxonomy 146: 1-18. http://dx.doi.org/10.5852/ ejt.2015.146

\section{Introduction}

The millipede order Spirostreptida is mainly distributed in the tropical and temperate zones of the Southern Hemisphere, and in warm-temperate North America. In the Palaearctic subregion there are 
some marginal occurrences in East Asia, and very few, disjunct occurrences in the western Palaearctic: Odontostreptus spp. in Morocco, Archispirostreptus spp. in the Middle East, and the so far monotypic genus Chiraziulus Mauriès, 1983, in Iran (Shelley \& Golovatch 2011: fig. 29). Whereas Odontostreptus Attems, 1914 and Archispirostreptus Silvestri, 1895 belong to the family Spirostreptidae, suborder Spirostreptidea, Chiraziulus is the only W Palaearctic representative of the suborder Cambalidea (Shelley \& Golovatch 2011: fig. 30).

Chiraziulus and its type species, C. kaiseri, were described by Mauriès (1983) who erected it as a subgenus of Nannolene Bollman, 1887. Golovatch (1983) tentatively suggested that full generic status might be warranted for Chiraziulus, and Mauriès (1987) listed it as a full genus. Nannolene, in its current conception (Hoffman 1999), includes numerous nominal species from the western USA and the Hawaiian Islands. Although relationships within Cambalidae are not at all clear, and the delimitation of the family vis-à-vis other cambalidean families is equally uncertain (Enghoff $e t$ al. in press), the fact remains that Chiraziulus is a highly disjunct genus, separated from all other Cambalidea by distances of over $2000 \mathrm{~km}$; if its closest relative is really Nannolene, the distance will surpass $7000 \mathrm{~km}$.

Iran is located in a biogeographically interesting transition area, but the cave-adapted fauna of the country is still poorly known (Malek Hosseini et al. 2015). The Zagros Mountains are rich in caves, and many remain unexplored. This mountain range extends from Turkey and Iraq to Iran, and is oriented from northwest to southeast, comprising nearly one-fifth of the surface area of Iran. Only eight caveadapted species (i.e., troglobionts for terrestrials and stygobionts for aquatics) have been recorded from Iran so far: four amphipods, Niphargus alisadri Esmaeili-Rineh \& Sari, 2013; N. daniali EsmaeiliRineh \& Sari, 2013; N. khayyami Hekmatara, Zakšek, Heidari Baladehi \& Fišer, 2013 and N. valachicus Dobreanu \& Manolache, 1933; one terrestrial isopod, Protracheoniscus gakalicus Kashani, Malek Hosseini \& Sadeghi, 2013; one species of goblin spider, Oonopidae, Trilacuna qarzi Malek Hosseini \& Grismado, 2015; and two cave fishes, the barb Gara typhlops Bruun \& Kaiser, 1944 and the loach Paracobitis smithi Smith, 1976 (Esmaeili-Rineh \& Sari 2013; Hekmatara et al. 2013; Kashani et al. 2013; Malek Hosseini et al. 2015).

We revise the genus Chiraziulus, describe a new species from a cave in Iran and document intraspecific variation of $C$. kaiseri. New observations on the flagellum in a species of the North American genus Cambala Gray, 1832, are also included. Re-examination of the type material of C. kaiseri led to the discovery of the presence of ectoparasitic fungi of the order Laboulbeniales; we also include information about this infection.

\section{Material and methods}

New specimens of Chiraziulus (Fig. 1) were collected in two caves in Iran: Ghar Sarab Cave (Ghar is Persian for "cave"), located at $87 \mathrm{~km}$ northwest of Hamadan city, near Sarab village, altitude: $2200 \mathrm{~m}$ asl, coordinates $35^{\circ} 14^{\prime} 41.7^{\prime \prime} \mathrm{N}, 48^{\circ} 15^{\prime} 40.6^{\prime \prime} \mathrm{E}$, length: $2959.9 \mathrm{~m}$ and Neyneh Cave, located at $45 \mathrm{~km}$ southwest of Dehdasht city, Kohgiluyeh and Boyerahmad Province, coordinates 30 40'18' N, 50 $21^{\prime}$ '71' E, $770 \mathrm{~m}$ asl (Fig. 2).

Specimens were studied using a Leica Wild M10 microscope equipped with an ocular micrometer. Parts of specimens were mounted in glycerine on temporary slides for microscope study. Microphotographs were taken using a Leica digital camera M205A mounted on a stereo microscope Leica DFC 420. Images were processed with a Leica Application Suite program, and final stacking was made using ZereneStacker software. For scanning electron microscopy, parts of specimens were critical point dried in a Tousimis Autosamdi 815, series A. Other specimens were transferred to $96 \%$ ethanol, then to acetone, air-dried, mounted on aluminium stubs, coated with platinum/palladium and studied in a JEOL JSM-6335F scanning electron microscope. Images were processed with Adobe Photoshop CS6. 
Material is deposited in the Zoological Museum, Natural History Museum of Denmark, University of Copenhagen (ZMUC), the Collection of the Biology Department, Zoological Museum of Shiraz University, Shiraz, Iran (ZM CBSU) and the Natural History Museum of Vienna (NHMW).

\section{Results}

\section{Systematics}

Class Diplopoda Blainville-Gervais, 1844

Order Spirostreptida Brandt, 1833

Suborder Cambalidea Cook, 1895

Family Cambalidae Bollman, 1893

Genus Chiraziulus Mauriès, 1983

Nannolene (Chiraziulus) Mauriès, 1983: 250

Chiraziulus (as full genus) - Mauriès 1987: 197.

\section{Type species}

Nannolene (Chiraziulus) kaiseri Mauriès, 1983.

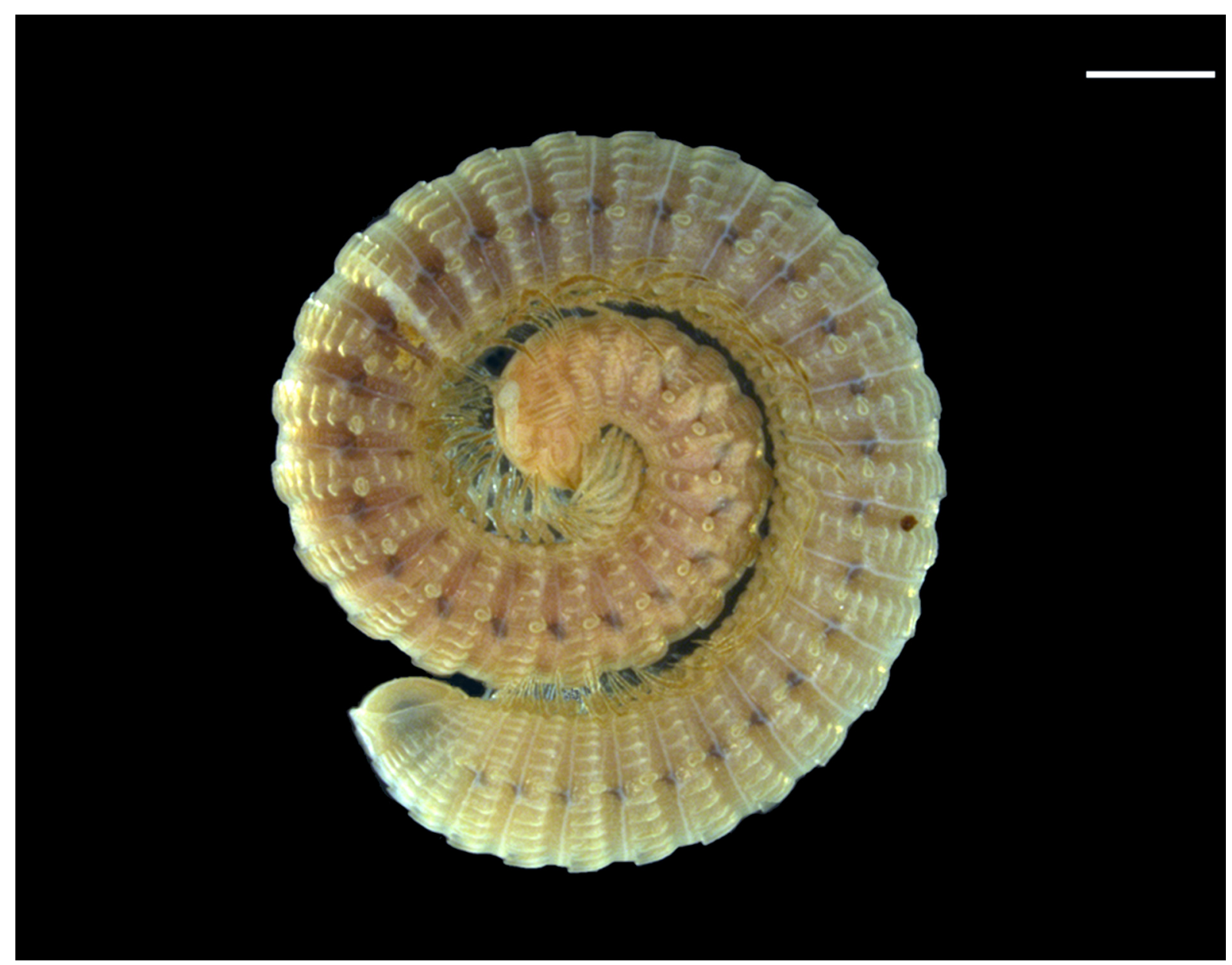

Fig. 1. Habitus of Chiraziulus troglopersicus sp. nov., paratype. 


\section{Diagnosis}

A genus of medium-sized blind cambalid millipedes resembling the Nearctic genus Nannolene, with longitudinal crests on the body rings and ozopores placed on prominent tubercles (Fig. 1). Sharing with Nannolene remarkably long gonopodal flagella, which make a complete loop $\left(360^{\circ}\right)$ from their insertion points on the anterior gonopods towards the interior part of the posterior gonopods, differing from Nannolene by having the coxites of the anterior gonopods larger than the telopodites. First pair of male legs not modified.

\section{Distribution}

Iran (Fig. 2).

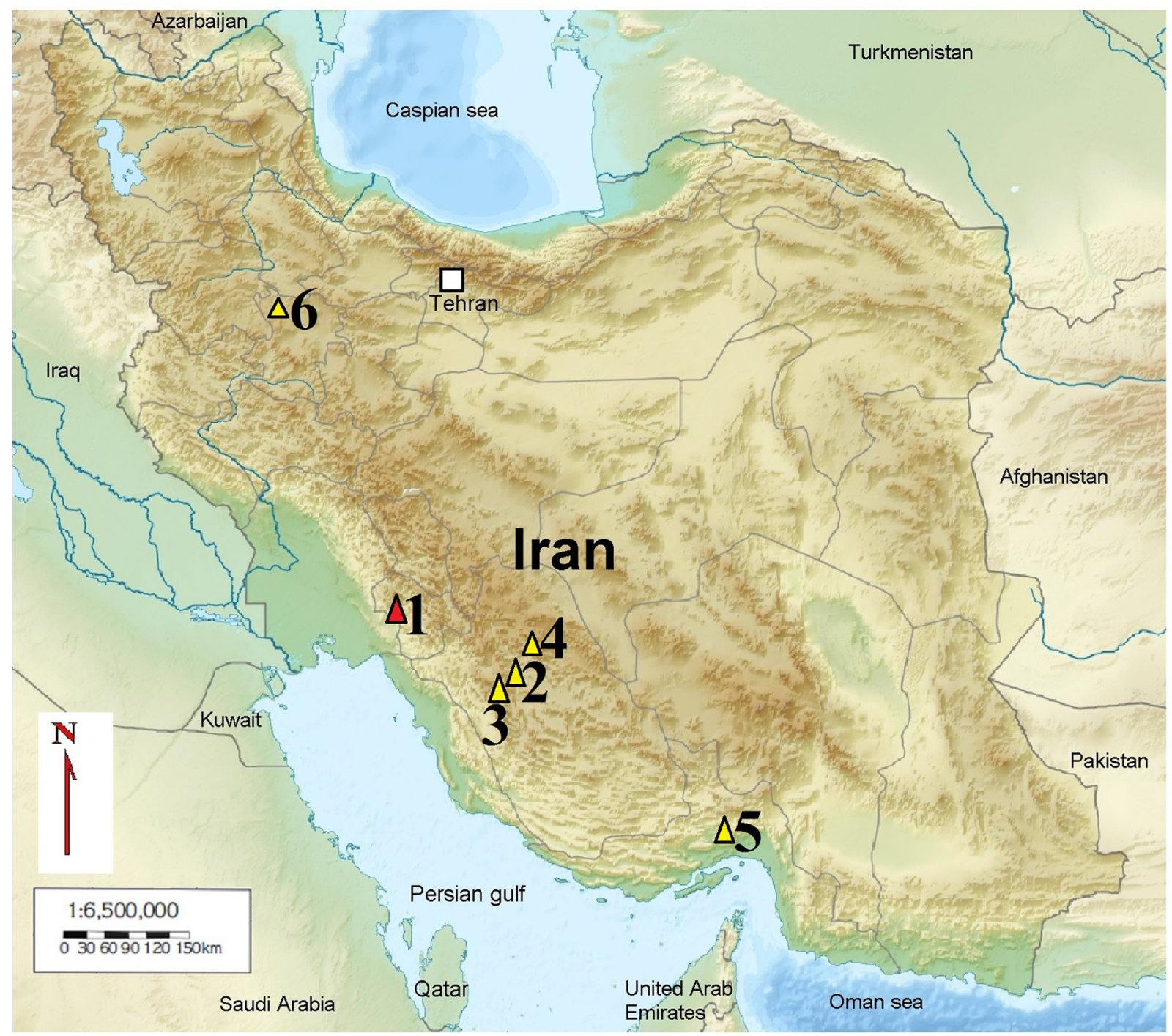

Fig. 2. Distribution of species of Chiraziulus Mauriès, 1983 in Iran (Mauriès 1987). C. troglopersicus sp. nov.: red dot (1); C. kaiseri: yellow dots (2-6). 1. Neyneh Cave. 2. "Chiraz" "montagne greseuse au nord de la ville". 3. $19 \mathrm{~km} \mathrm{~W}$ of Shiraz. $4.5 \mathrm{~km} \mathrm{~N}$ of Persepolis. 5. Oasis $95 \mathrm{~km} \mathrm{~N}$ of Bandarabass. 6. Sarab Cave. 
Chiraziulus kaiseri (Mauriès, 1983)

Figs 3-8, 11-12

Nannolene (Chiraziulus) kaiseri Mauriès, 1983: 252, figs 4-10.

Nannolene (Chiraziulus) kaiseri - Golovatch 1983: 166.

Chiraziulus kaiseri - Enghoff \& Moravvej 2005: 63.
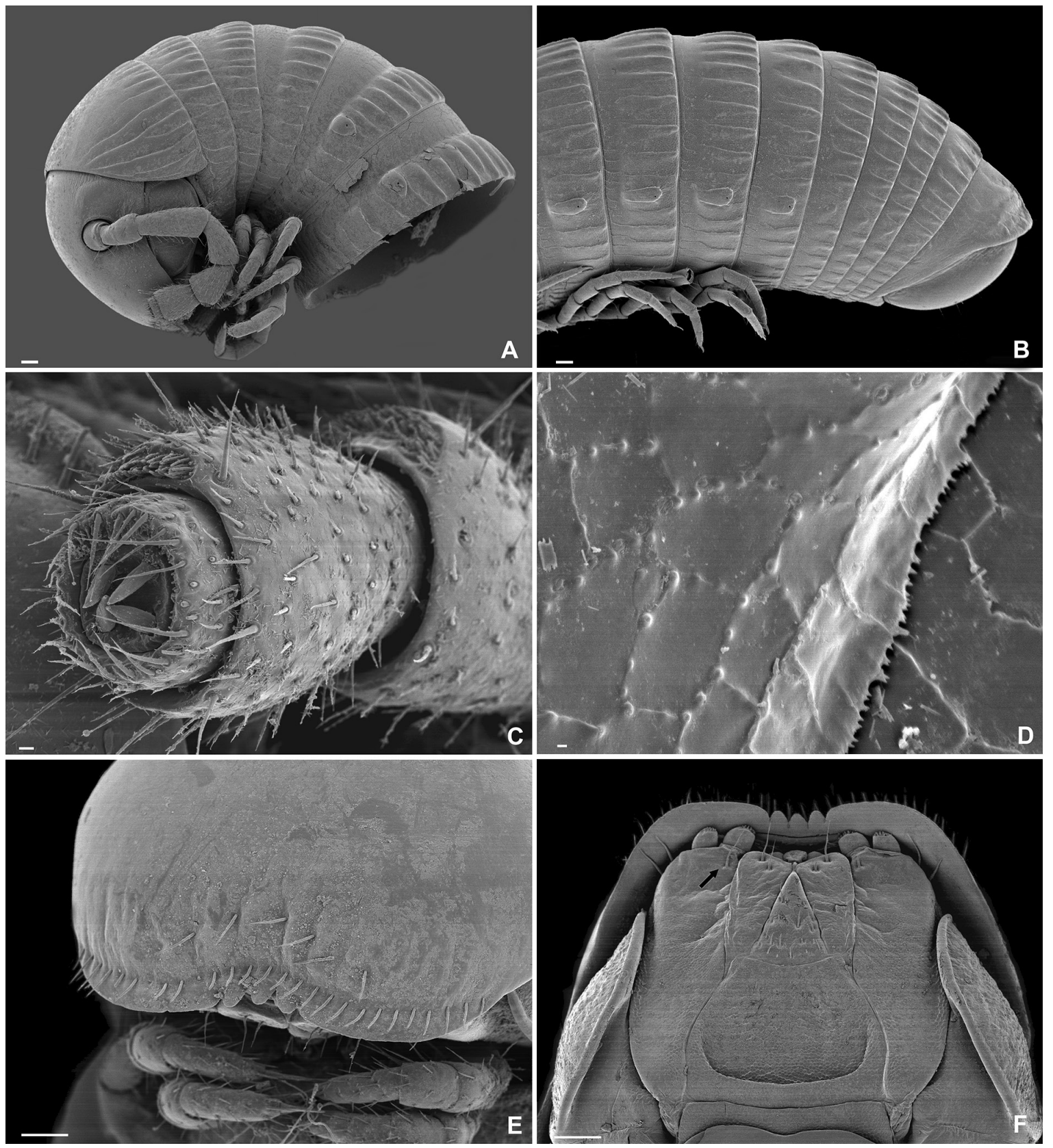

Fig. 3. Chiraziulus kaiseri (Mauriès, 1983), paratypes. Scanning electron micrographs. A. Head and first body rings in lateral view. B. Last body rings ("tail") in lateral view. C. Tip of antenna. D. Detail of the limbus; notice lines of beadlike structures between cuticular scutes. E. Detail of labrum in frontal view. F. Gnathochilarium in ventral view; the arrow shows the distomesal setae on stipes. Scale bars: A-B, $\mathrm{E}-\mathrm{F}=100 \mu \mathrm{m} ; \mathrm{C}=10 \mu \mathrm{m} ; \mathrm{D}=1 \mu \mathrm{m}$. 


\section{Diagnosis}

A species of Chiraziulus, differing from C. troglopersicus sp. nov. by having triangular anterior gonopods in anterior view, the posterior branch of the telepodite smaller than the anterior branch, and the posterior gonopod with a simple, sharp, spinelike process.

\section{Type material examined}

IRAN: Holotype ( $\left.\delta^{(}\right)$and numerous paratypes, Shiraz, sandstone mountains $\mathrm{N}$ of the town, $1600 \mathrm{~m}$ asl. Very dry, scattered vegetation including the first spring flowers, under stones and clods, 16 Feb. 1937, E.W. Kaiser leg. (ZMUC).

\section{Additional material examined}

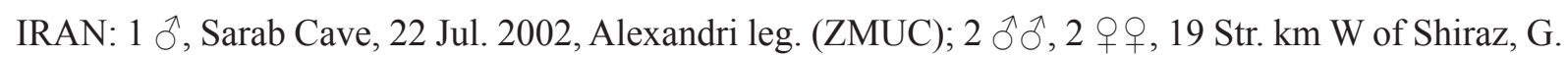
Pretzmann leg. (NHMW).

\section{Description}

Eyes absent, body depigmented, with prominent tergal crests. Ozopores on protruding tubercles, starting on $5^{\text {th }}$ body ring (Fig. 3A, B). Antenna with four long apical cones and bacilliform sensilla seated in small depressions on external part of the $5^{\text {th }}$ and $6^{\text {th }}$ antennomeres (Fig. 3C). Labrum and supralabral chaetotaxy as in Fig. 3E. Gnathochilarial stipes with three setae, two distolateral and one distomesal seta, the latter close to promentum. Lingual lamella with two setae. Promentum moderately setose (Fig. 3F). Limbus with numerous tiny denticles (Fig. 3D). Borders between cuticular scutes on part of body with lines of beadlike structures (Fig. 3D), similar to those observed by Akkari \& Enghoff (2011) and Enghoff (2014) in other millipedes.

\section{Male}

Anterior gonopods (Figs 4, 5A-F) with tongue-shaped, parallel-sided mid-sternal lobe. Each coxite approximately like an equilateral triangle folded at right angles along vertical axis; resulting surfaces facing anteriad and mesad; coxite hence narrow triangular in anterior view, ending in rather sharp point (Fig. 5A); coxite in mesal view with a plane surface traversed by oblique groove for accommodation of flagellum (Fig. 4); posterior margin sinuous, in apical view c. 30\% of it with rugose-scaly microsculpture

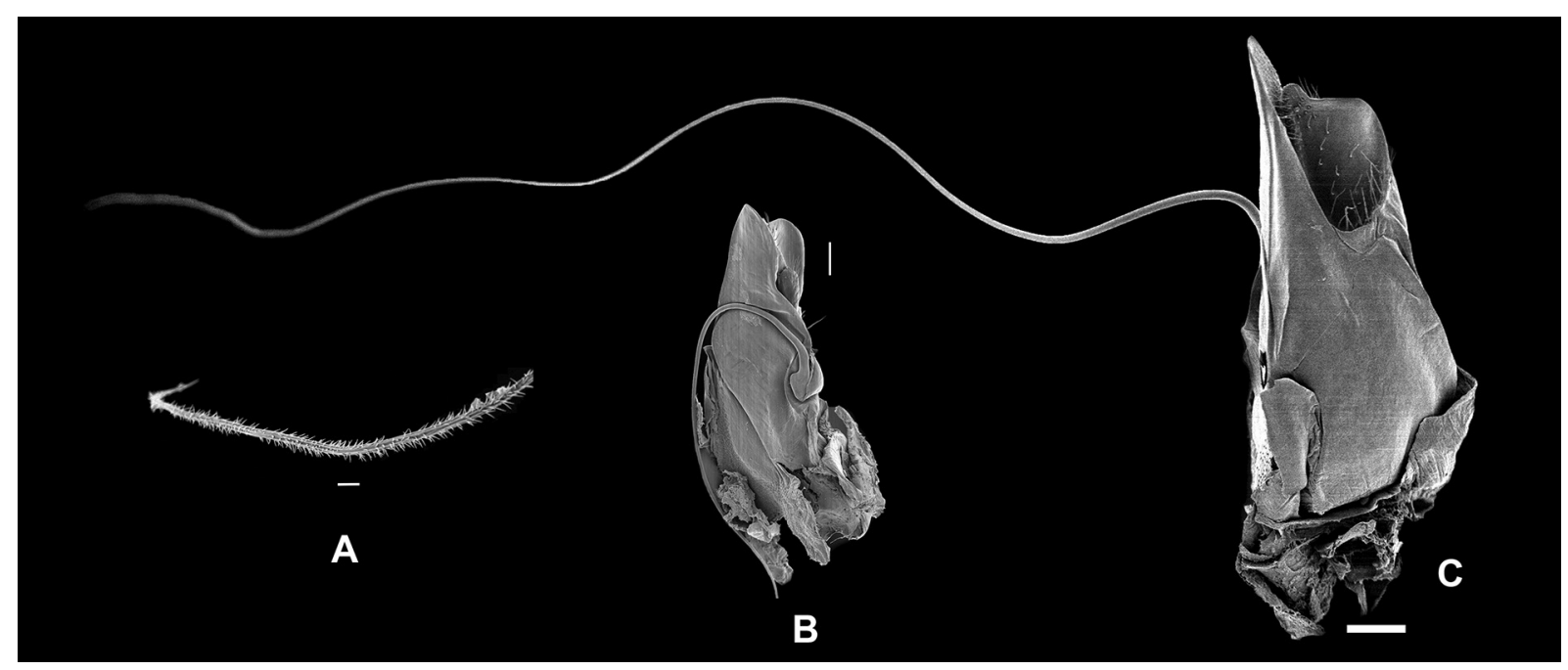

Fig. 4. Chiraziulus kaiseri (Mauriès, 1983), đ̂, paratype, anterior gonopod. Scanning electron micrographs. A. Tip of flagellum. B. Flagellum insertion and loop across anterior gonopod coxite. C. Anterior gonopod showing the entire extension of the flagellum. Scale bars: $A=10 \mu \mathrm{m} ; \mathrm{B}-\mathrm{C}=100 \mu \mathrm{m}$. 

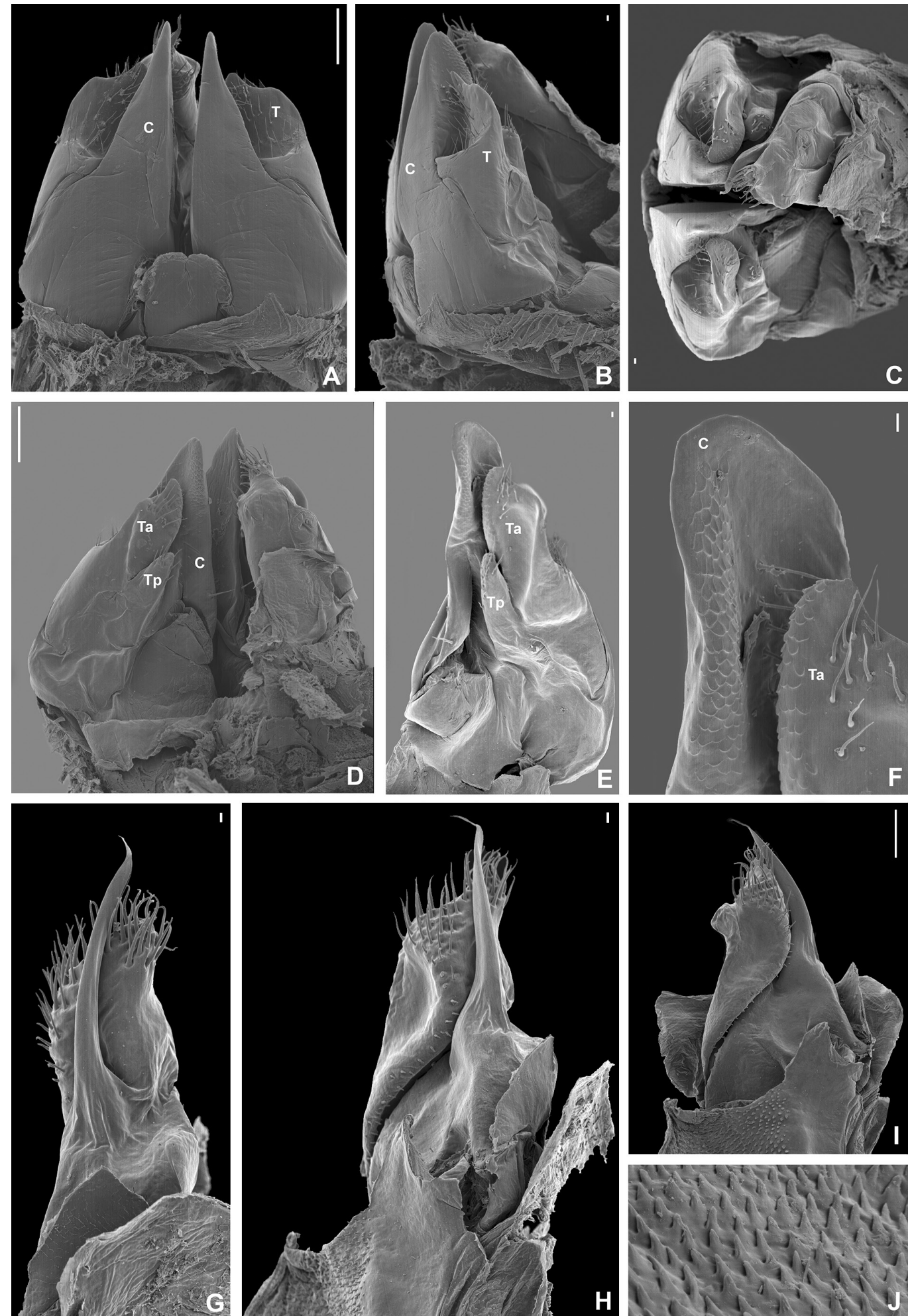

Fig. 5. Chiraziulus kaiseri (Mauriès, 1983), Ô, paratypes, gonopods. Scanning electron micrographs. A. Anterior gonopods in anterior view. B. Anterior gonopods with one posterior gonopod in lateral view. C. As B, in apical view. D. As B, in posterior view. E-F. Anterior gonopod with detail of the processes on the tip of anterior gonopods. G-I. Posterior gonopod. J. Detail of the mesal sternal part. Abbreviations: $\mathrm{C}=$ coxal process; $\mathrm{T}=$ telepodite; $\mathrm{Ta}=$ anterior lobe of telopodite; $\mathrm{Tb}=$ posterior lobe of telepodite. Scale bars: A, D, I $=100 \mu \mathrm{m} ; \mathrm{B}-\mathrm{C}, \mathrm{E}-\mathrm{H}=10 \mu \mathrm{m}$. 

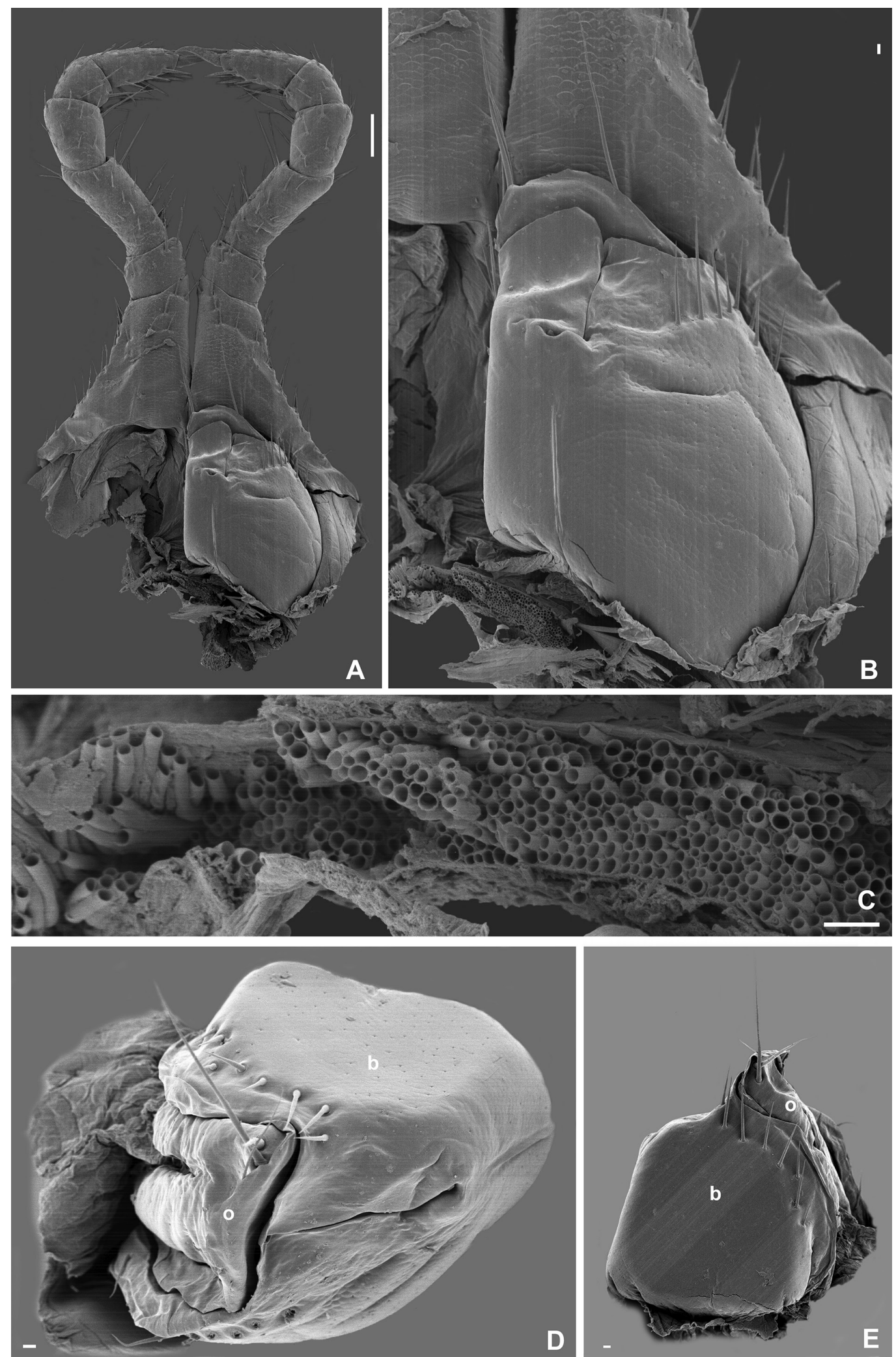

Fig. 6. Chiraziulus kaiseri (Mauriès, 1983), female vulva. Scanning electron micrographs. A. Vulva in situ behind second pair of legs, posterior view. B. Details of right vulva behind second pair of legs. C. Detail of microtubular structure under the vulva. D. Vulva in ventral view. E. Vulva in anterior view. Abbreviations: $\mathrm{o}=$ operculum; $\mathrm{b}=$ bursa. Scale bars: $\mathrm{A}=100 \mu \mathrm{m} ; \mathrm{B}-\mathrm{E}=10 \mu \mathrm{m}$. 
on lateral surface. Telopodite large, two-lobed; anterior lobe (regarded as part of the coxite (e) by Mauriès) larger ( $\mathrm{Ta}$ ), but not reaching tip of coxite (Fig. 5D-E), apical margin concave (Fig. 5F); in anterior view Ta broadly visible lateral to coxite, with transverse "step", distal to 'step' with several setae; in posterior view $T a$ longitudinally concave, apically with several setae and with mesal margin (facing rugosity of coxite) rugose; posterior lobe of telopodite $(T p)(\mathrm{T}=$ telopodite of Mauriès) much shorter than $T a$, rod-
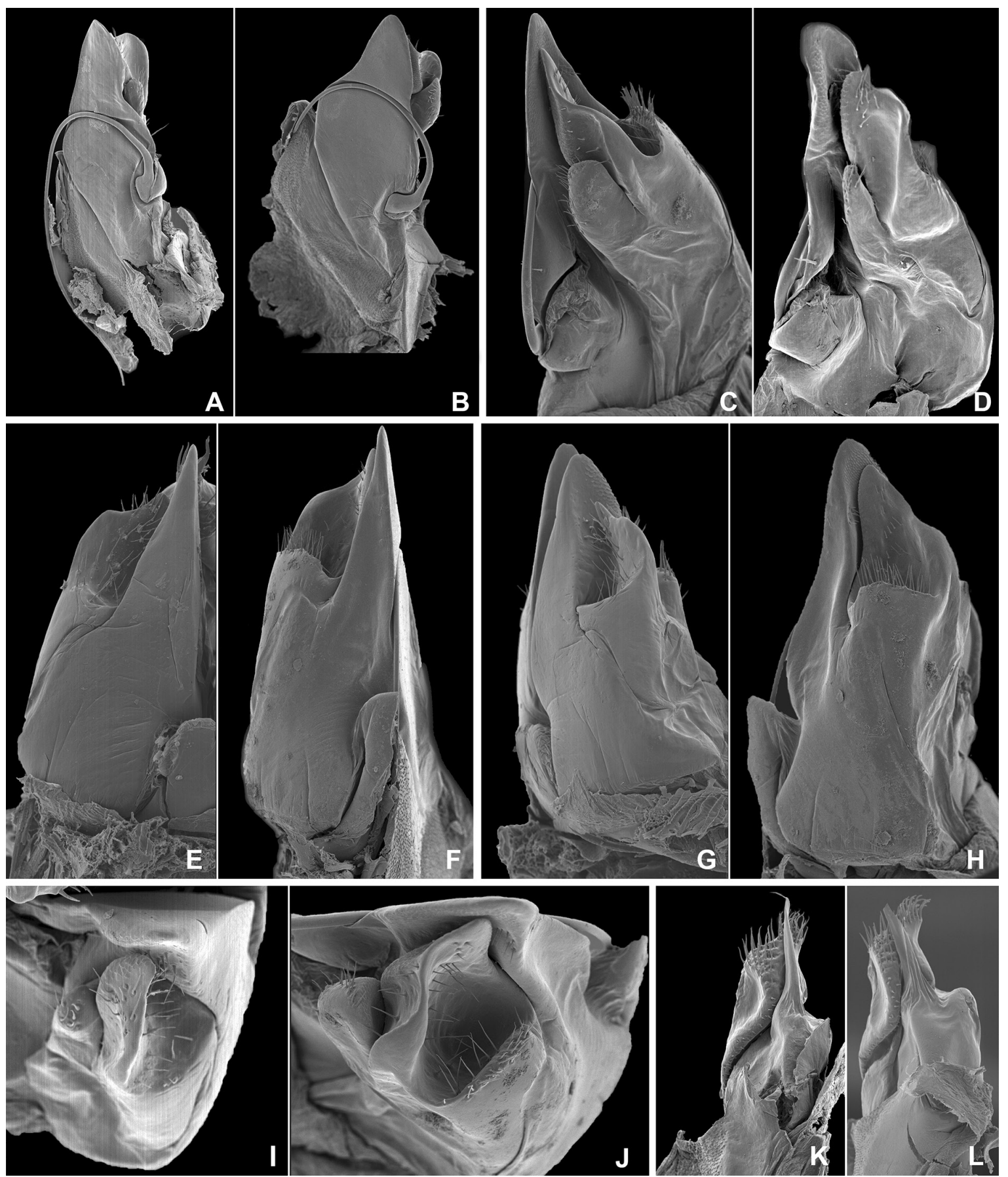

Fig. 7. Chiraziulus kaiseri (Mauriès, 1983). Comparison of the paratype (A, C, E, G, I and K) and specimen from Ghar Sarab Cave (B, D, F, H, J and L). A-B. Left anterior gonopods, mesal view. C-D. Anterior gonopod, posterior view. E-F. Anterior gonopod, anterior view. G-H. Anterior gonopod, lateral view. I-J. Anterior gonopod, apical view. K-L. Posterior gonopods. 
shaped, apically broadly rounded, with several setae (Fig. 5D). Rugose tips of coxite and telepodite (Ta) of anterior gonopod forming a pair of "forceps" (Fig. 5F). Flagellum exceedingly long, inserted below mid-height of posterior margin of coxite, initially directed distad, then turning anteriad and traversing mesal surface of coxite in slightly curved groove, then turning basad-posteriad, probably accommodated in basal oblique groove (Fig. 4B-C); apical part of flagellum densely covered with $c .5 \mu \mathrm{m}$ long hairlike, retrorse processes (Fig. 4A). Posterior gonopods (Fig. 5G-I) apically covered with setae and with a long slender, spine-like, apically twisted process. Mesal sternal part of gonopods forming trough densely covered with sharktooth-like denticles (Fig. 5J).

\section{Female}

Vulva in situ as in Fig. 6A-B. Peculiar, microtubular tissue present below insertion level of bursa (Fig. 6C). Operculum (o) smaller than bursa, with 2 large apical setae; bursa massive, enveloping operculum, with simple slit-shaped crest and $8+8$ setae along distal margins (Fig. 6D, E).

\section{Distribution}

Known from several localities in Iran (Fig. 2).

\section{Intrapecific variability of Chiraziulus kaiseri}

In addition to the type locality and a few sites in its vicinity, Chiraziulus kaiseri has been recorded from the south of Iran (Golovatch 1983). Examination of an adult male from an isolated cave (Sarab Cave) in northwestern Iran, far from the type locality, leads us to include it in C. kaiseri as well and to regard the differences in the male gonopods as intraspecific variability (Fig. 7).

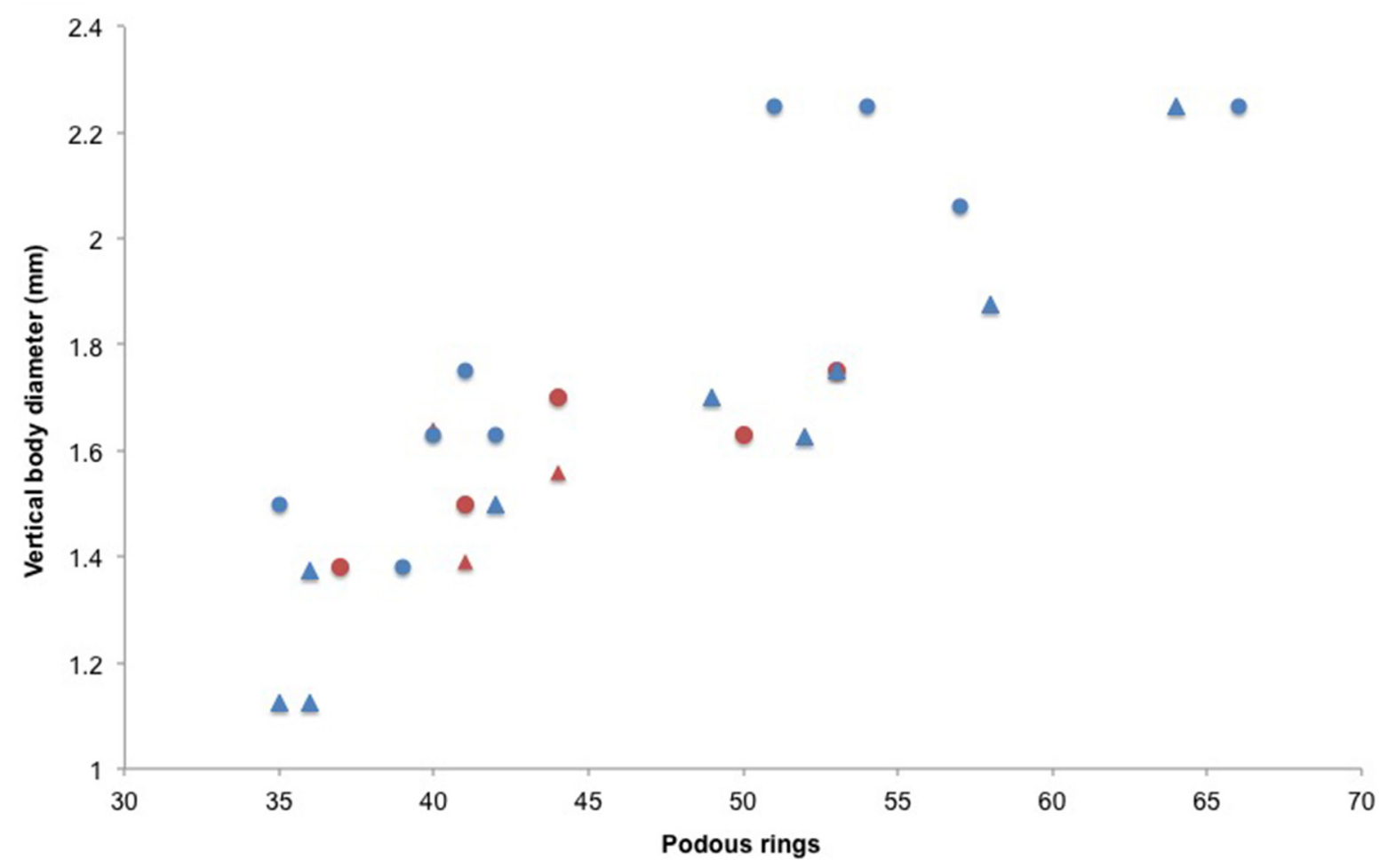

Fig. 8. Number of podous rings and midbody vertical diameter of the studied specimens. Chiraziulus kaiseri (Mauriès, 1983) in blue; Chiraziulus troglopersicus sp. nov. in red. $\mathbf{\Delta}=$ adult $\widehat{\partial} \hat{\delta} ; \bullet=$ juveniles and 우. 
The anterior gonopods of the specimen from Sarab Cave shows some differences compared to the type material, especially in the shape of the posterior branch of the telepodite (Fig. 7E-J). No remarkable difference was observed in the posterior gonopods (Fig. 7K-L). Some variability was also observed in the chaetotaxy of the gnathochilarial stipes (Fig. 3F). In the specimens from the type locality, Sarab Cave and $19 \mathrm{~km} \mathrm{~W}$ of Shiraz, there are two distolateral and one distomesal setae, whereas in the specimen illustrated by Golovatch (1983: 168, fig. 12), all three setae are distolateral.

Chiraziulus troglopersicus sp. nov.

urn:1sid:zoobank.org:act:B8EF3E4B-E658-4CC6-B4DE-8045734547EE

Figs 1, 9-10

\section{Diagnosis}

A species of Chiraziulus, differing from C. kaiseri by anterior gonopods not presenting a triangular shape in anterior view, by having equally sized anterior and posterior lobes of anterior gonopod telepodites, and by posterior gonopod having a spine-like process ending in a halberd-like structure.

\section{Etymology}

From Greek trōglo: cave, common prefix for terrestrial cave-dwelling animals, and Latin persicus: Iranian.

\section{Type material}

\section{Holotype}

IRAN: $\widehat{\jmath}$, Kohgiluyeh and Boyerahmad Province, Khaeiz protected area, Mt. Khaeiz, $45 \mathrm{~km}$ southwest of Dehdasht city, Neyneh Cave, 3040'18” N, 50²1'71' E, altitude 770 m (gonopods coated for SEM), 17 May 2012 (ZMUC).

\section{Paratypes}

IRAN: same data as the holotype: 4 ㅇq (ZMUC); 1 q and 3 के 0 (ZM CBSU).

\section{Description}

Males: $41-44$ podous +2 apodous rings, diameter $1.39-1.64 \mathrm{~mm}$. Females: $39-51$ podous +2 apodous rings, and $53+0$ podous rings, diameter $1.38-1.75 \mathrm{~mm}$. Habitus typical of the genus, eyes absent. Six supralabral setae. Ozopore starting on $5^{\text {th }}$ body ring (except for one female paratype that presents teratological traits and in which ozopores start on $6^{\text {th }}$ body ring).

\section{Male (Fig. 9)}

Anterior gonopods (Fig. 9A-D) with remarkably long flagellum (Fig. 9A, D-E), making a full loop from its insertion point on posterior face of anterior gonopod coxites pointing distad. Anterior gonopods with blade-shaped and apically rounded coxite (not of a triangular shape in anterior view as in C. kaiseri) (Fig. 9A-D); each coxite with 2 setae in mesal anterior view ( $s$ ) (Fig. 9B) and a lateral ridge with 4 setae at mid-height $(d p)$; external lateral margin slightly concave, with rugose-scaly microsculpture (Fig. 9B). Telepodite shorter than coxite, bi-lobed (Figs. 9A-D). Anterior and posterior lobes of telepodite ( $\mathrm{Ta}$ and $T p$ ) about the same size; anterior lobe with 8 setae, slightly concave on side facing posterior lobe; posterior lobe with 8 parallel setae. Flagellum $(f)$ extremely long, covered with $c$. $5 \mu \mathrm{m}$ long hair-like, retrorse processes and a pointed tip (Fig. 9E). Posterior gonopods (Fig. 9F-J) apically covered with setae and with a long slender spine-like process ending in a halberd-like expansion. Mesal sternal part of gonopods forming a trough covered with sharktooth-like denticles (Fig. 9I-J). 

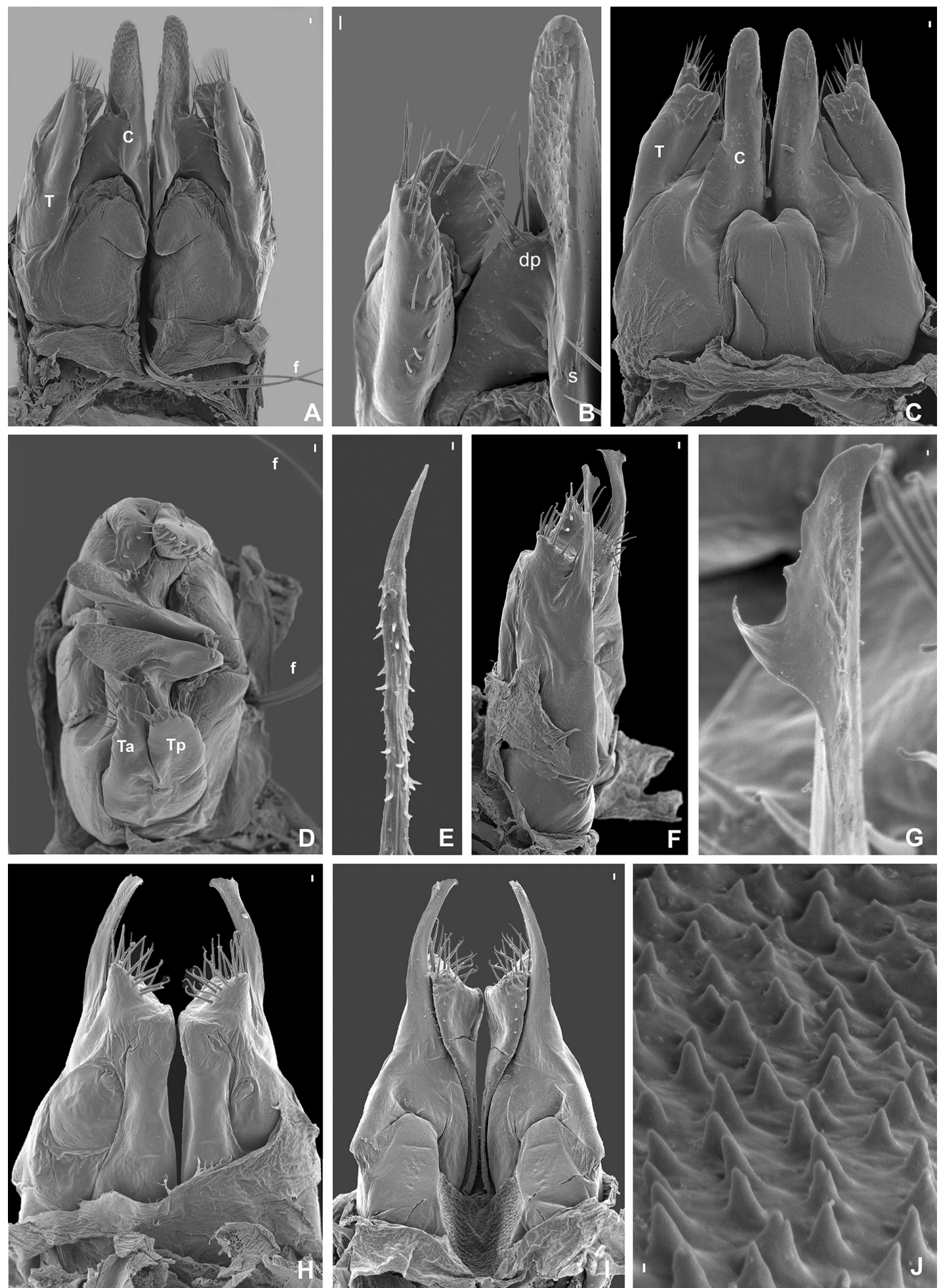

Fig. 9. Chiraziulus troglopersicus sp. nov., $\widehat{\partial}$, paratype, gonopods. Scanning electron micrographs. A. Anterior gonopods in posterior view. B. Detail of the process on the tip of an anterior gonopod in posterior view. C. Anterior gonopods in anterior view. D. As C, in apical view. E. Tip of the flagellum. F. Posterior gonopods in lateral view. G. Tip of the long spine-like process of the posterior gonopod. H. Posterior gonopods in posterior view. I. As H, in anterior view. J. Detail of the mesal sternal part of the gonopods. Abbreviations: $\mathrm{C}=$ coxal process; $\mathrm{T}=$ telepodite; $\mathrm{f}=$ flagellum; $\mathrm{s}=$ setae; $\mathrm{dp}=$ distal process. Scale bars: A-D, F, H-I $=10 \mu \mathrm{m} ; \mathrm{E}, \mathrm{G}, \mathrm{J}=1 \mu \mathrm{m}$. 


\section{Habitat}

The new species was discovered in the Neyneh Cave (Fig. 10), located in the mountainous Khaeiz protected area, in Zagros Mountains, southwestern Iran. Neyneh Cave is situated in the warmer part of the province where the temperature at the surface reaches to $50^{\circ} \mathrm{C}$ during the summer. The temperature inside the cave is $25^{\circ} \mathrm{C}$; the relative humidity is very high, $95-99.9 \%$, and the $\mathrm{CO}_{2}$ level is $613-700 \mathrm{ppm}$. There was no water flow in the cave. This cave is located in cliffs and has more than $700 \mathrm{~m}$ of horizontal maze development. It is located in an area with difficult access, thus protected from human pressure; however, there is some destruction due to the activities of treasure hunters. Chiraziulus troglopersicus sp. nov. specimens were found in complete darkness, crawling on guano and cave walls. Some colonies of bats produce enough guano to cover the cave soil, providing an important source of organic matter for this subterranean trophic chain. Species richness in Neyneh Cave is relatively high and includes several arthropod taxa (Acari, Araneae, Oniscidea, Collembola, Orthoptera, Coleoptera), as well as some vertebrate taxa, such as gekkos, bats and hystricid rodents.

\section{Notes on the gonopods of Cambala annulata (Say, 1821)}

SEM study of one male of Cambala annulata (USA, NC, Surry Co., Elkin, 12 October 1975, R.M. Shelley leg.) revealed that the anterior gonopod in this species, like that of Chiraziulus (and Nannolene), has a remarkably long flagellum (Fig. 11A) with a similar insertion, and with a similar full-loop course in part involving a groove on the mesal side of the anterior gonopod coxite. The sharktooth-like structure of the mesal gonopodal sternal part is also present (Fig. 11B).

\section{Occurrence of ectoparasitic fungi on Chiraziulus kaiseri}

Studies of the obligate ectoparasitic fungi of the order Laboulbeniales associated with millipedes are scarce (e.g., De Kesel et al. 2013; Santamaria et al. 2014; Enghoff \& Santamaria 2015; Reboleira \&

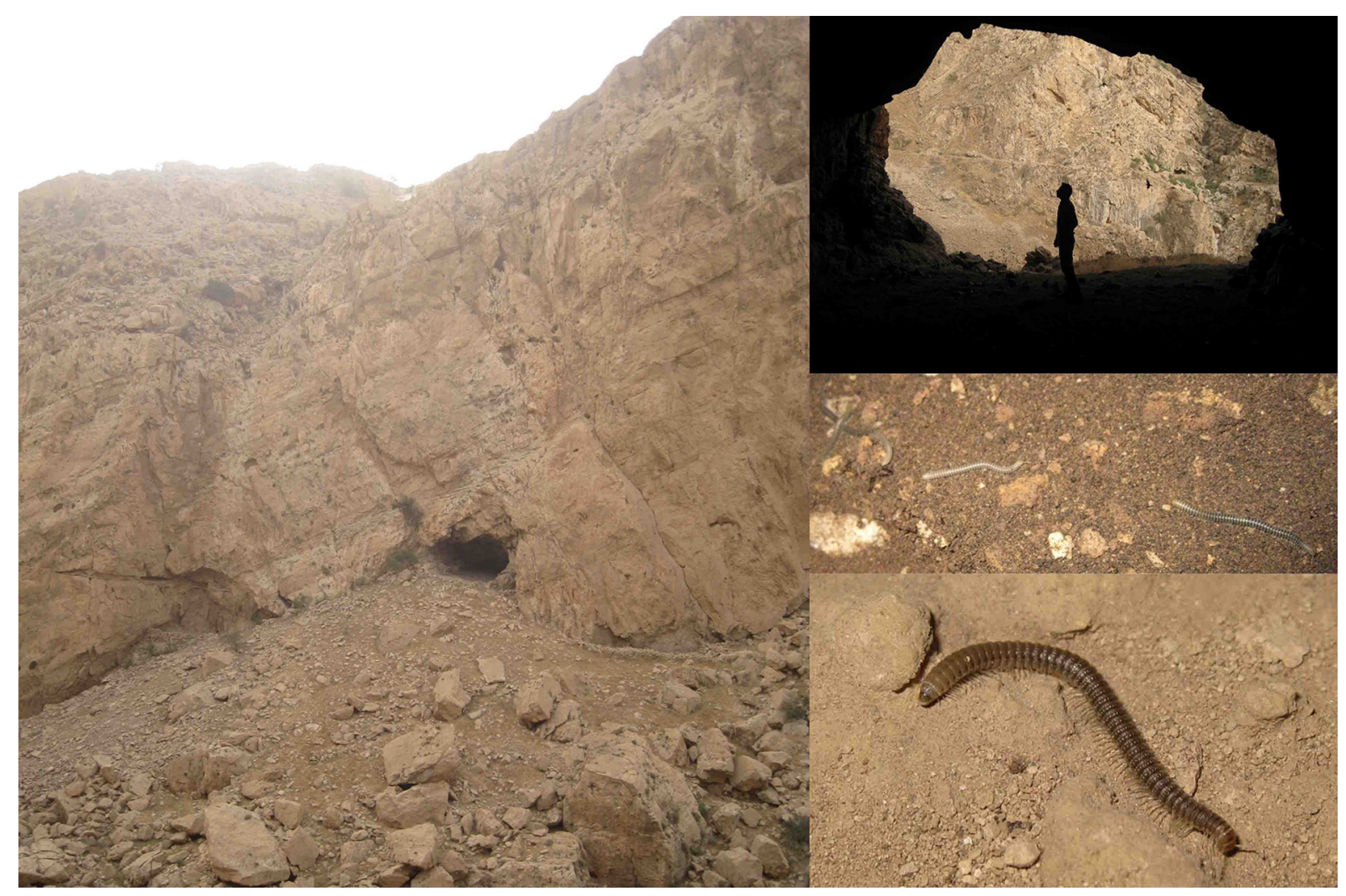

Fig. 10. Chiraziulus troglopersicus sp. nov., habitat; Neyneh Cave in Zagros Mountains, Iran. 


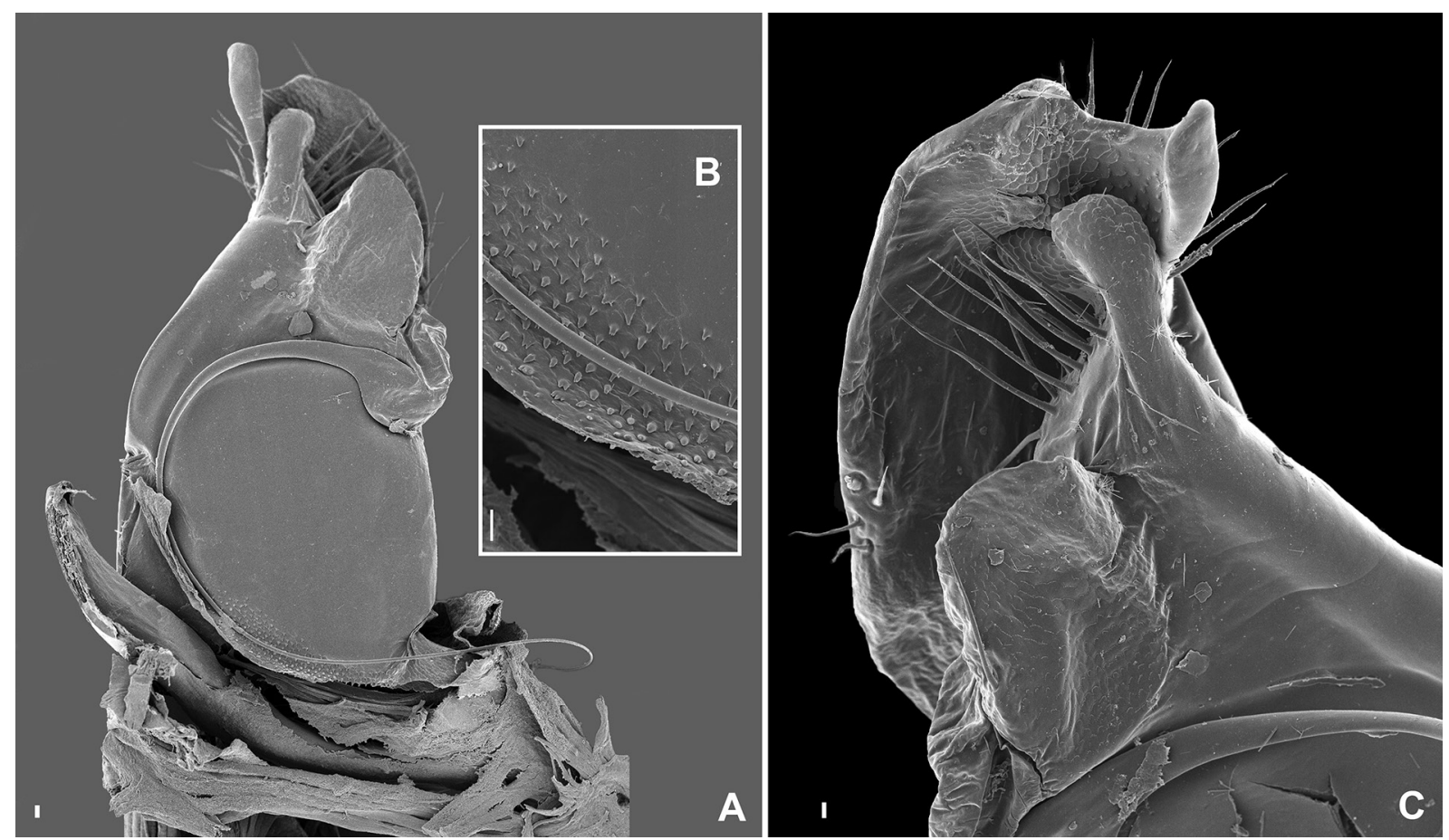

Fig. 11. Cambala annulata (Say, 1821), anterior gonopod. A. Mesal view. B. Detail of the mesal sternal part. C. Apical part of coxal processes and telepodite. Scale bars: A $=100 \mu \mathrm{m} ; \mathrm{B}-\mathrm{C}=10 \mu \mathrm{m}$.
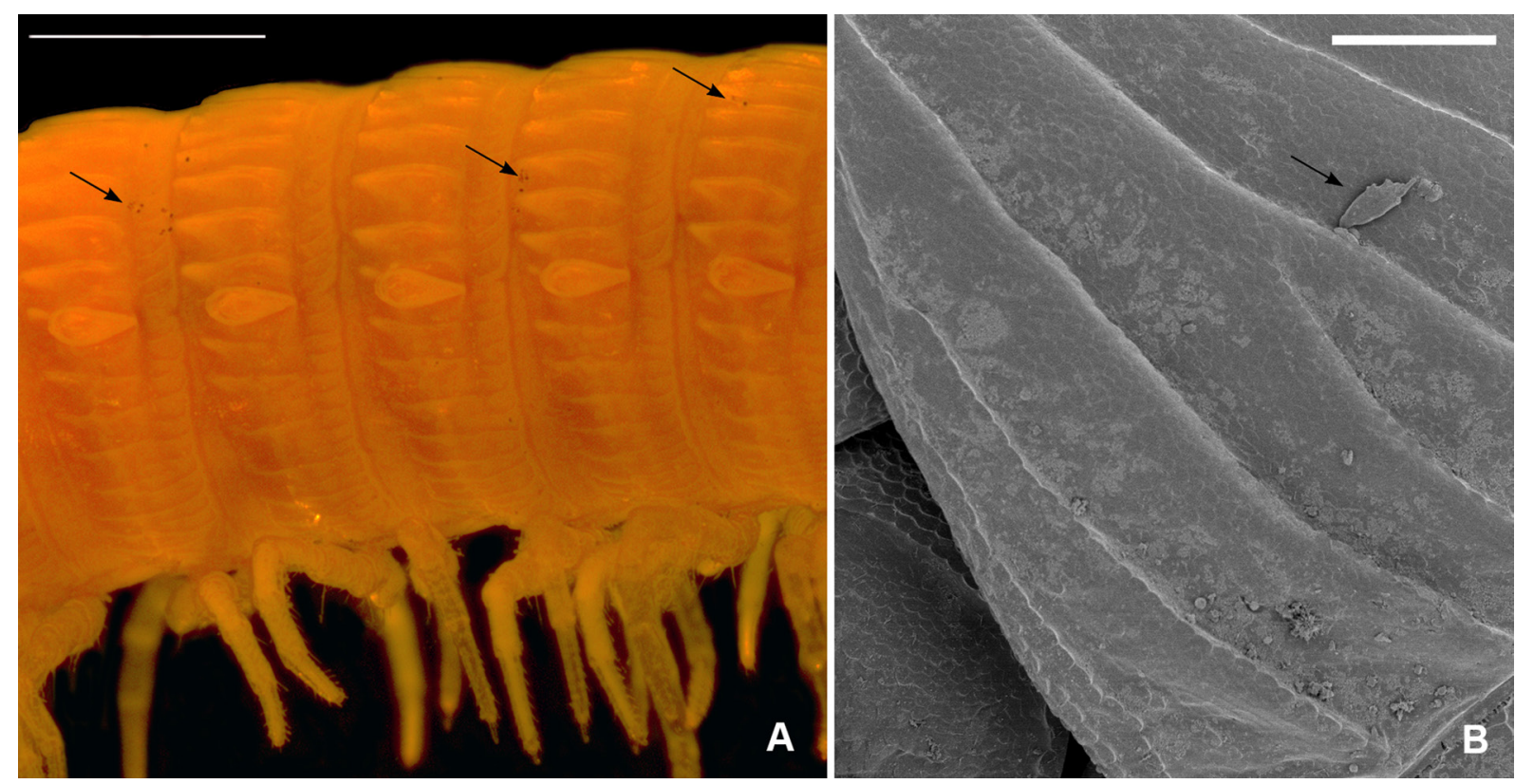

Fig. 12. Chiraziulus kaiseri (Mauriès, 1983), paratypes infected with ectoparasitic fungi of the genus Rickia Cavara, order Laboulbeniales. A. Arrows indicate black dots on the body rings corresponding to the insertion of the fungi. B. Scanning electron micrograph of the collum with one fungus (arrow). Scale bars: $\mathrm{A}=1 \mathrm{~mm} ; \mathrm{B}=100 \mu \mathrm{m}$. 
Table 1. Numbers of Chiraziulus kaiseri (Mauriès, 1983) specimens infected with the ectoparasitic fungus Rickia sp.

\begin{tabular}{|l|c|c|c|c|}
\cline { 2 - 5 } \multicolumn{1}{c|}{} & \multicolumn{2}{c|}{ Infected } & \multicolumn{2}{c|}{ Non-infected } \\
\cline { 2 - 5 } \multicolumn{1}{c|}{} & Male & Female & Male & Female \\
\hline Type locality & 30 & 31 & 2 & 2 \\
19 km W of Shiraz & 2 & 2 & - & - \\
Sarab Cave & 1 & - & - & - \\
\hline
\end{tabular}

Enghoff 2015). These fungi live only on the surface of living animals, and during the revision of the type material of Chiraziulus kaiseri, deposited in ZMUC (Fig. 12), almost all type specimens were found to be infected with an undescribed species of the genus Rickia, which in spite of its small size can be detected due to the dark coloration of the foot and appendages (Fig. 12A).

Some Laboulbeniales have a preference for growing on specific parts of the millipede body, and the transmission mechanisms play an important role for the position of the fungus on the host (Enghoff \& Santamaria 2015; Reboleira \& Enghoff 2015). In the case of Rickia sp. on C. kaiseri, the fungus is randomly distributed along the millipede (Fig. 12): it was found on body rings, legs, head, antennae and surprisingly also on the paraprocts (anal valves), both in adults and juveniles, suggesting that transmission does not exclusively take place during copulation as occurs in other species (Santamaria et al. 2014).

Of the 70 specimens studied, 66 where infected, which means that the infection rate may be around $94 \%$ (Table 1). This is significantly higher than the $64 \%$ infection rate recorded for populations in caves of the callipodidan Lusitanipus alternans (Verhoeff, 1893), infected with Diplopodomyces lusitanipodos Santam., Enghoff \& Reboleira in central Portugal, and than the 63\% recorded for the blaniulid Archiboreoiulus pallidus (Brade-Birks, 1920) infected with Troglomyces triandrus Santam. \& Enghoff, but still lower than the 100\% infections reported for Troglomyces pusillus Santam. \& Enghoff on the blaniulid Iberoiulus cavernicola Ceuca, 1967 (Enghoff \& Santamaria 2015; Reboleira \& Enghoff 2015). The four specimens from $19 \mathrm{~km} \mathrm{~W}$ of Shiraz were also all infected.

More remarkably, the specimen of Chiraziulus kaiseri from Sarab Cave, despite being part of a disjunct population in the north of Iran, was also infected with the same species of Rickia.

\section{Discussion}

Chiraziulus kaiseri presents a considerable degree of intraspecific variation even within the type material. The new population found isolated in a cave in the northwest of Iran is also parasitized by the same Rickia (morpho)species as the type material. These fungi are normally highly host specific (De Kesel 1996), and the presence of the same ectoparasitic species in disjunct populations is herewith recorded for the second time for millipedes, as it was recently reported for Diplopodomyces lusitanipodos Santam., Enghoff \& Reboleira and Troglomyces manfrediae Colla (Santamaria et al. 2014).

The highly relict character of the genus Chiraziulus had already been pointed out by Golovatch (1983), due to its remarkable disjunct distribution relative to other Cambalidae, which are distributed mainly in North and Central America, Hawaii and Australia. The closest relative of Chiraziulus may be Nannolene (including Hawaicambala Mauriès, 1983), as suggested by the original classification of C. kaiseri in Nannolene (Mauriès 1983). A synapomorphy could be the exceedingly long gonopodal flagellum which from its insertion point on the posterior face of the anterior gonopod coxites points distad instead of basad or basad-posteriad as in most other flagelliferous Cambalidea (and Julida), and then makes a full 
$\left(360^{\circ}\right)$ loop. Illustrations of the flagellar loop in some Hawaiian and Californian species of Nannolene are provided by Silvestri (1904: figs 28-29) and Chamberlin (1922: pl. 1, fig. 6), respectively. However, not all Nannolene species have such extraordinary flagella (see, e.g., Silvestri 1904: fig. 19); also a specimen of Nannolene keiferi Chamberlin, 1943, has flagella of normal length which do not make the $360^{\circ}$ loop. On the other hand, we could show that this peculiar type of flagellum is also present in the genus Cambala. Clearly, the genus-level taxonomy and phylogeny of Cambalidae needs a closer study.

Mauriès (1983) mentioned the following characters in support of his new subgenus Chiraziulus:

1. Anterior gonopod coxites with much longer parasagittal lobes than in Nannolene s.s.

2. First pair of male legs unmodified (although there is some uncertainty about the first pair of legs in Nannolene s.s.)

3. Lack of eyes

4. Presence of longitudinal crests and grooves on the metaterga

5. The geographical isolation

We can support the first and fourth of these characters, although we have re-interpreted the "parties coxales parasagittales" as belonging to the telopodites. The second, third and fifth characters are less convincing: the male of $N$. keiferi that we have examined has unmodified first legs, several (sub)genera of, e.g., Julidae and Blaniulidae include eyed as well as blind species, and finally, geographical isolation per se should not be used as an argument for creating a new taxon, as this could easily lead to circular argumentation. For the time being, we maintain Chiraziulus as a full genus, following Mauriès (1987).

The microtrichose flagellum in both species of Chiraziulus is probably used for sperm competition, cf. Barnett \& Telford (1996), Enghoff (1985, 1992, 1995) and Frederiksen \& Enghoff (2015).

The anterior gonopod coxite and telopodite in Chiraziulus seem to form a "forceps" with the opposing scaly-rugose edges. This is probably an analogue of the "forceps" formed by the promerite (= anterior gonopod) and mesomerite (part of posterior gonopod) in several Julidae, which has been shown to grip the operculum of the vulva during copulation (Haacker \& Fuchs 1970; Tadler 1996; see also Read 1990). Mauriès interpreted both parts of the forceps as belonging to the coxite, but the SEM images clearly show that it is composed of apical parts of the coxite and the anterior branch of the telopodite.

We here add a cave-adapted millipede to the short list of Iranian cave fauna by describing a new species of Chiraziulus, raising to ten the number of cave-adapted species known for the country.

\section{Acknowledgements}

This project was funded by the Danish Council for Independent Research, ref. DFF-FNU 4002-00269 and the Iran National Science Foundation (INSF-89002421). Dr. Carles Ribera donated the specimens of C. kaiseri from Sarab Cave, Dr. R.M. Shelley, Radford, North Carolina, donated specimens of Cambala annulata and Nannolene keiferi, and Dr. Nesrine Akkari kindly loaned specimens deposited in NHMW. Dr. Sergi Santamaria, Barcelona, kindly confirmed the generic affiliation of the ectoparasitic fungus. We are indebted to Mr. Gholam Reza Haghbin and the environmental monitoring station officers of the Khaeiz protected area that guided MJMH to the cave with warm hospitality.

\section{References}

Akkari N. \& Enghoff H. 2011. On some surface structures of potential taxonomic importance in families of the suborders Polydesmidea and Dalodesmidea (Polydesmida, Diplopoda). Zookeys 156: 1-24. http:// dx.doi.org/10.3897/zookeys.156.2134 
Barnett M. \& Telford S.R. 1996. Sperm competition and the evolution of millipede genitalia. In: Geoffroy J.-J., Mauries J.-P. \& Nguyen Duy-Jacquemin M. (eds) Acta Myriapodologica: 331-339. Mémoires du Muséum national d'Histoire naturelle 169, Muséum national d'Histoire naturelle, Paris.

Chamberlin R.V. 1922. Notes on West Indian millipedes. Proceeding of the United States National Museum 61 (10): 1-19.

De Kesel A. 1996. Host specificity and habitat preference of Laboulbenia slackensis. Mycologia 88 (4): 565-573. http://dx.doi.org/10.2307/3761150

De Kesel A., Haelewaters D. \& Gerstmans C. 2013. Two interesting species of Rickia (Laboulbeniales) from coastal habitats in Belgium and the Netherlands. Sterbeeckia 32: 6-10.

Enghoff H. 1985. The millipede family Nemasomatidae. With the description of a new genus, and a revision of Orinisobates (Diplopoda: Julida). Entomologica Scandinavica 16 (1): 27-67. http://dx.doi. org/10.1163/187631285X00045

Enghoff H. 1992. Dolichoiulus - a mostly Macaronesian multitude of millipedes. With the description of a related new genus from Tenerife, Canary Islands (Diplopoda, Julida, Julidae). Entomologica Scandinavica, Supplement 40: 1-158.

Enghoff H. 1995. A revision of the Paectophyllini and Calyptophyllini: millipedes of the Middle East (Diplopoda, Julida, Julidae). Journal of Natural History 29: 685-786. http://dx.doi. org/10.1080/00222939500770241

Enghoff H. 2014. A mountain of millipedes I: An endemic species-group of the genus Chaleponcus Attems, 1914, from the Udzungwa Mountains, Tanzania (Diplopoda, Spirostreptida, Odontopygidae). European Journal of Taxonomy 100: 1-75. http://dx.doi.org/10.5852/ejt.2014.100

Enghoff H. \& Moravvej S.A. 2005. A review of the millipede fauna of Iran (Diplopoda). Zoology in the Middle East 35: 61-72. http://dx.doi.org/10.1080/09397140.2005.10638104

Enghoff H. \& Santamaria S. 2015. Infectious intimacy and contaminated caves - three new species of ectoparasitic fungi (Ascomycota: Laboulbeniales) from blaniulid millipedes (Diplopoda: Julida) and inferences about their transmittal mechanisms. Organisms, Diversity and Evolution 15 (2): 249-263. http://dx.doi.org/10.1007/s13127-015-0208-8

Enghoff H., Golovatch S., Short M., Stoev P. \& Wesener T. In press. Diplopoda - Taxonomic overview. In: Minelli A. (ed) The Myriapoda 2. Treatise on Zoology - Anatomy, Taxonomy, Biology. Brill, Leiden.

Esmaeili-Rineh S. \& Sari A. 2013. Two new species of Niphargus Schiödte, 1849 (Crustacea: Amphipoda: Niphargidae) from two caves in Iran. Journal of Natural History 47 (41-42): 2649-2669. http://dx.doi. org/10.1080/00222933.2013.802041

Frederiksen S.B. \& Enghoff H. 2015. East African odontopygid millipedes 4: A restricted redefinition of the genus Rhamphidarpoides Kraus, 1960, a related new genus, five new species, and notes on solenomere function (Diplopoda; Spirostreptida; Odontopygidae). Zootaxa 3926 (1): 541-60. http:// dx.doi.org/10.11646/zootaxa.3926.4.5

Golovatch S.I. 1983. A contribution to the millipede fauna of Iran (Diplopoda). Annalen des naturhistorischen Museums Wien 85/B: 157-169.

Haacker U. \& Fuchs S. 1970. Das Paarungsverhalten von Cylindroiulus punctatus Leach. Zeitschrift für Tierpsychologie 27 (6): 641-648. http://dx.doi.org/10.1111/j.1439-0310.1970.tb01892.x

Hekmatara M., Zakžek V., Heidari B.M. \& Fišer C. 2013. Two new species of Niphargus (Crustacea: Amphipoda) from Iran. Journal of Natural History 47 (21-22): 1421-1449. http://dx.doi.org/10.1080/ $\underline{00222933.2012 .743616}$ 
Hoffman R.L. 1999. Checklist of Millipeds of North and Middle America. Special Publication 9, Virginia Museum of Natural History, Martinsville.

Kashani G.M., Malek Hosseini M.J. \& Sadeghi S. 2013. First recorded cave-dwelling terrestrial isopods (Isopoda: Oniscidea) in Iran with a description of a new species. Zootaxa 3734 (5): 591-596. http:// dx.doi.org/10.11646/zootaxa.3734.5.8

Malek Hosseini M.J., Grismado C., Sadeghi S. \& Bakhshi Y. 2015. Description of the first cave dwelling species of the spider genus Trilacuna Tong \& Li from Iran (Araneae: Oonopidae). Zootaxa 3972 (4): 549-561. http://dx.doi.org/10.11646/zootaxa.3972.4.6

Mauriès J.-P. 1983. Cambalides nouveaux et peut connus d'Asie, d'Amérique et d'Océanie. I. Cambalidae et Cambalopsidae (Myriapoda, Diplopoda). Bulletin du Muséum national d'Histoire naturelle Paris, section A, 4e série 5 (1): 247-276.

Mauriès J.-P. 1987. Cambalides nouveaux et peut connus d'Asie, d'Amérique et d'Océanie. II. Pseudonannolenidae, Choctellidae (Myriapoda, Diplopoda). Bulletin du Muséum national d'Histoire naturelle Paris, section A, 4e série 9 (1): 169-199.

Read H.J. 1990. The generic composition and relationships of the Cylindroiulini - a cladistic analysis (Diplopoda, Julida: Julidae). Entomologica Scandinavica 21: 97-112. http://dx.doi. org/10.1163/187631290X00085

Reboleira A.S.P.S. \& Enghoff H. 2015. Redescription of Lusitanipus alternans (Verhoeff, 1893) (Diplopoda, Callipoda, Dorypetalidae) and ecological data on its Laboulbeniales ectoparasites in caves. Zootaxa 3957 (5): 567-576.

Santamaria S., Enghoff H. \& Reboleira A.S.P.S. 2014. Laboulbeniales on millipedes: the genera Diplopodomyces and Troglomyces. Mycologia 106 (5): 1027-1038. http://dx.doi.org/10.3852/13-381

Shelley R.M. \& Golovatch S.I. 2011. Atlas of myriapod biogeography. I. Indigenous ordinal and supraordinal distributions in the Diplopoda: perspective on taxon origins and ages, and a hypothesis on the origin and early evolution of the class. Insecta Mundi 158: 1-134.

Silvestri F. 1904. Myriopoda. In: Sharp D. (ed.) Fauna Hawaiiensis. Vol. 3: 323-338. The University Press, Cambridge. http://dx.doi.org/10.5962/bhl.title.4628

Tadler A. 1996. Functional morphology of genitalia of four species of julidan millipedes (Diplopoda: Nemasomatidae; Julidae). Zoological Journal of the Linnean Society 118: 83-97. http://dx.doi. org/10.1111/j.1096-3642.1996.tb01263.x

Manuscript received: 22 June 2015

Manuscript accepted: 12 August 2015

Published on: 22 October 2015

Topic editor: Rudy Jocqué

Desk editor: Charlotte Thionois

Printed versions of all papers are also deposited in the libraries of the institutes that are members of the EJT consortium: Muséum national d'Histoire naturelle, Paris, France; Botanic Garden Meise, Belgium; Royal Museum for Central Africa, Tervuren, Belgium; Natural History Museum, London, United Kingdom; Royal Belgian Institute of Natural Sciences, Brussels, Belgium; Natural History Museum of Denmark, Copenhagen, Denmark. 